\title{
Textile Analysis and Interpretation for Decision Making
}

\author{
Usha Chowdhary* and Stanley Mathews \\ Central Michigan University, USA
}

*Corresponding author: Usha Chowdhary, Professor, Human Environmental Studies, Central Michigan University, Mount Pleasant, MI 48859, USA

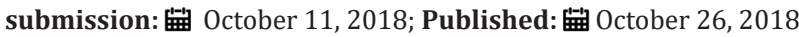

\section{Mini Review}

Textile industry is actively involved in promoting quality products for textile and apparel. Despite society's move to the casual lifestyle, need for lined garments has not disappeared. When selecting lined garments, it is of critical importance that apparel manufacturers test the appropriateness of each layer for the intended end-use and compatibility of all layers together. It is important to consider both structural and performance attributes while making such decisions from the available choices. Chowdhary [1] reported that crimp in yarn makes the synthetic filaments more resilient than the uncrimped yarns. Likewise, twist adds strength for the staple fibers when twisted to make yarns. Higher fabric count is associated with better quality than the lower count. Quality fabrics also mean defect free textiles. Breaking strength was higher for twill weave as opposed to plain and sateen weave [2]. Uttam [3] found that cotton became heavier and thicker with increased cover factor after repeated washing.

Chowdhary [4] asserted that dimensional stability can be used to determine fabric shrinkage and /or growth after care. This statement has merit because using two different fiber contents (cotton and acetate lining) for a lined garment may change differentially and allow decision-makers either to change the care procedure or choose different fabric. Horizontal wicking is also an important performance attribute because it helps with moisture management for the wearer. In any garment appearance, comfort, ease of care and durability are important considerations. Compatibility should also be considered for lined garments [1].

For the reported study, five structural and five performance attributes were chosen to make decision for a lined dress. Structural textile attributes included fiber content (AATCC 20, 2013), yarn type, fabric construction (ASTM D579-01), fabric count (ASTM D3775-12), and fabric weight (ASTM D3776-2013) were selected as structural attributes. Performance attributes represented appearance retention (AATCC 124-2001), dimensional stability (AATCC 96, 2001), horizontal wicking (AATCC 198 2013), pilling resistance (ASTM D 3512-02), and tearing strength ASTM D 2261-96). All tests were performed following instructions from Wroblewski SM [5]. It is important to mention that lining should be slippery to allow easy donning and doffing of the garment. Acetate has been used extensively for lining in the industry. Therefore, acetate was chosen [6].

Findings revealed that fashion fabric was made from $100 \%$ cotton, single yarns, light weight, high count, and plain weave. Lining was made from $100 \%$ acetate, single yarns, light weight, high count, and plain weave. Except for fiber content, two fabrics were similar for structural attributes (Table 1).

Table 1: Structural textile attributes for cotton fashion fabric and acetate lining.

\begin{tabular}{|c|c|c|c|}
\hline $\begin{array}{c}\text { Structural Attri- } \\
\text { butes }\end{array}$ & $\begin{array}{c}\text { Fashion } \\
\text { Fabric }\end{array}$ & Lining & Compatibility \\
\hline Fiber Content & Cotton & Acetate & No \\
\hline Yarn Type & Single & Single & Yes \\
\hline Fabric Construction & Woven & Woven & Yes \\
\hline \multirow{2}{*}{ Fabric Count } & $\begin{array}{c}124 \times 83= \\
207\end{array}$ & $\begin{array}{c}175 \mathrm{x} \\
76=231\end{array}$ \\
\cline { 2 - 4 } & High & High & Yes \\
\hline \multirow{2}{*}{ Fabric Weight } & 2.812 ozs $/ \mathrm{yd}^{2}$ & $\begin{array}{c}2.611 \text { ozs/ } \\
\text { yd }^{2}\end{array}$ & \\
\cline { 2 - 5 } & Light Weight & Light Weight & Yes \\
\hline
\end{tabular}

Table 2: Performance textile attributes for cotton fashion fabric and acetate lining.

\begin{tabular}{|c|c|c|c|}
\hline $\begin{array}{c}\text { Performance Attri- } \\
\text { butes }\end{array}$ & $\begin{array}{c}\text { Fashion } \\
\text { Fabric }\end{array}$ & Lining & Compatibility \\
\hline $\begin{array}{c}\text { Dimensional Stability } \\
(\%)\end{array}$ & $\begin{array}{c}\text { Warp } \\
1.24 \%\end{array}$ & $2.78 \%$ & Not Compatible \\
\cline { 2 - 4 } & $\begin{array}{c}\text { Weft } \\
0.69 \%\end{array}$ & $1.58 \%$ & \\
\hline Appearance Retention & 2.56 & 1.33 & Not compatible \\
\hline \multirow{2}{*}{ Pilling Resistance } & 5 & 5 & Compatible \\
\hline \multirow{2}{*}{ Tear Strength (psi) } & Warp 7.02 & 1.05 & \\
\cline { 2 - 5 } & Weft 3.3 & 1.04 & Not compatible \\
\hline
\end{tabular}




\begin{tabular}{|c|c|c|c|}
\hline $\begin{array}{c}\text { Horizontal Wicking } \\
\left(\mathrm{mm} / \mathrm{sec}^{2}\right)\end{array}$ & 4.438 & 32.235 & Not Compatible \\
\hline
\end{tabular}

Table 2 displays results for performance attributes. Results revealed that fabrics were not found to be compatible for performance attributes. Fashion fabric passed for dimensional stability but lining failed (Table 2). Therefore, two could not be used together for a lined garment unless dry cleaned. Both failed appearance retention test. However, ironing could be recommended to overcome this difference. A special care is required because two fabrics do not withstand same temperature level. Acetate could melt at the temperature that cotton yields the best results. Both passed pilling test. Horizontal wicking was much higher for acetate than cotton. Acetate will be next to skin as lining and it is good to have higher wicking for effective moisture management than the fashion fabric. Finally, lining failed the tear strength test, but cotton passed it. Two fabrics may be appropriate choices but results show that lining is weaker than the fashion fabric and will result in compromised durability.

Preceding information reveals that even though two fabrics are structurally compatible, they did not perform well together based on various performance attributes. This another way to determine appropriateness and compatability by comparing findings against the industry standards to assess if fabrics meet or exceed standards. Therefore, technical data sheets were developed for both fashion fabric and lining fabrics. Comparison against the standards reveals that fashion fabric passed three out of five tests and lining passed only one out of five tests. Therefore, these two fabrics were not compatible based on both type of testing.

\section{UCSM designs}

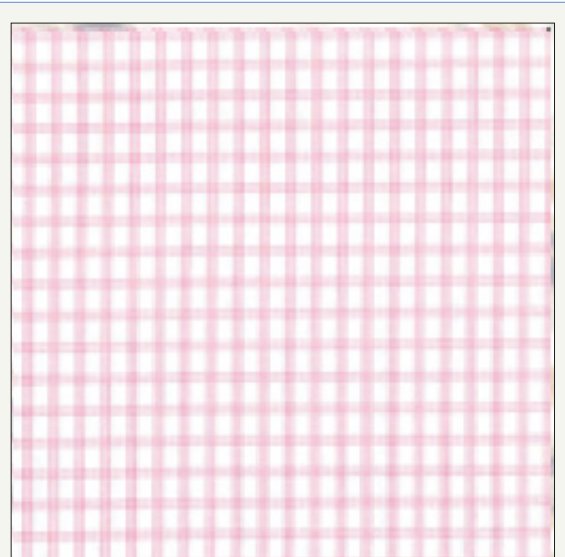

Figure 1: $100 \%$ cotton fabric, Price: $\$ 5.99 / \mathrm{yd}$.

Table 3: Structural attributes.

\begin{tabular}{|c|c|c|}
\hline Attribute & Finding & Classification \\
\hline Fiber Content & $100 \%$ Cotton & Cellulosic \\
\hline Yarn Type & $\begin{array}{c}\text { Untwisting } \\
\text { Showed Fibrous } \\
\text { Structures }\end{array}$ & Single Yarn \\
\hline Fabric Construction & $1 \times 1$ Repeat & Plain Weave \\
\hline Fabric Count & $124 \times 83=207$ & High \\
\hline
\end{tabular}

\begin{tabular}{|c|c|c|}
\hline Fabric Weight & $2.812 \mathrm{oz} / \mathrm{yd}^{2}$ & Light \\
\hline
\end{tabular}

Table 4: Performance attributes.

\begin{tabular}{|c|c|c|c|}
\hline Attribute & Finding & Standard & Pass/Fail \\
\hline Dimensional Stability & $\begin{array}{c}\text { Warp: } 1.24 \% \\
\text { Weft: } 0.69 \%\end{array}$ & $2 \%$ Max & Pass \\
\hline Appearance Retention & 2.56 & $\begin{array}{c}3.5 \text { Mini- } \\
\text { mum }\end{array}$ & Fail \\
\hline Pilling & 5 & $\geq 4$ & Pass \\
\hline Tear Strength & $\begin{array}{c}\text { Warp: } 7.02 \\
\text { PSI } \\
\text { Weft: } 3.30 \\
\text { PSI }\end{array}$ & $\begin{array}{c}2.5 \text { PSI } \\
\text { Minimum }^{2.438}\end{array}$ & Pass \\
\hline Horizontal Wicking & $\begin{array}{c}4.4 \mathrm{MM}^{2} / \mathrm{S} \\
78 \mathrm{MM}^{2} / \mathrm{s}\end{array}$ & Finimum \\
\hline
\end{tabular}

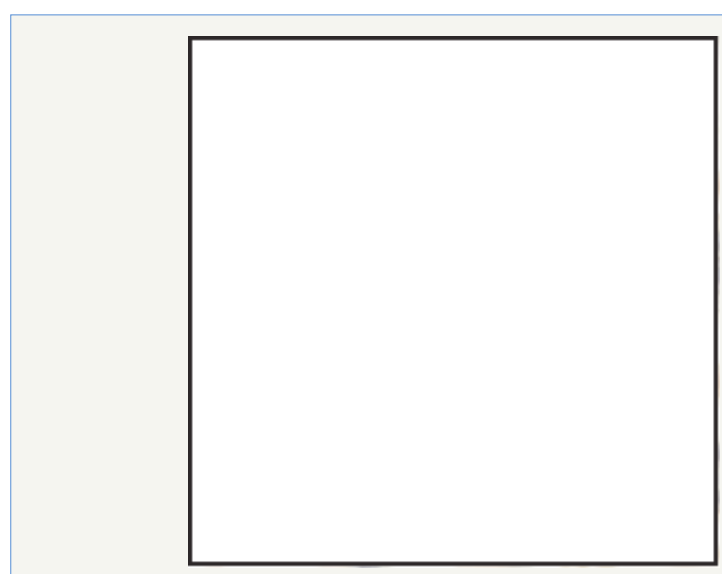

Figure 2: $100 \%$ acetate lining, Price: $\$ 3.99 / \mathrm{yd}$.

Table 5: Structural attributes.

\begin{tabular}{|c|c|c|}
\hline Attribute & Finding & Classification \\
\hline Fiber Content & $100 \%$ Acetate & Manmade Fiber \\
\hline Yarn Type & $\begin{array}{c}\text { Untwisted into Fila- } \\
\text { ments }\end{array}$ & Single Yarn \\
\hline Fabric Construction & $1 \times 1$ Repeat & Plain Weave \\
\hline Fabric Count & $175 \times 76=231$ & High \\
\hline Fabric Weight & $2.611 \mathrm{oz} / \mathrm{yd}^{2}$ & Light \\
\hline
\end{tabular}

Table 6: Performance attributes.

\begin{tabular}{|c|c|c|c|}
\hline Attribute & Finding & Standard & Pass/Fail \\
\hline $\begin{array}{c}\text { Dimensional } \\
\text { Stability }\end{array}$ & $\begin{array}{c}\text { Warp: } 2.78 \% \\
\text { Weft: } 1.58 \%\end{array}$ & $2 \%$ Max & Fail \\
\hline $\begin{array}{c}\text { Appearance Re- } \\
\text { tention }\end{array}$ & 1.33 Minimum & 3.5 Minimum & Fail \\
\hline Pilling & 5 & $\geq 4$ & Pass \\
\hline
\end{tabular}




\begin{tabular}{|c|c|c|c|}
\hline Tear Strength & $\begin{array}{c}\text { Warp: } 1.03 \\
\text { PSI } \\
\text { Weft: } 1.04 \text { PSI }\end{array}$ & 1.5 PSI Minimum & Fail \\
\hline $\begin{array}{c}\text { Horizontal Wick- } \\
\text { ing }\end{array}$ & 32.235 & Not Available & Fail \\
\hline
\end{tabular}

The research study can be duplicated in academic as well as industry settings. This methodology can be used for apparel product development process when making decisions to make final selection for a variety of fabrics and end uses. Using technical data sheets and same tests for all fabrics under consideration can enhance the efficiency of decision-making process. Communication between technical and executive team can be enhanced by using numbers simplistically and effectively [7]. The process can be further enhanced by using statistical testing to add objectivity in the selection process. For the reported study, t-values were computed to compare fashion fabric and lining for appearance retention and horizontal wicking. Results revealed that two fabrics differed significantly for these performance attributes and reinforced their non-compatibility. For the reported study, classification for fiber content was labeled as not applicable. If necessary, they could be labeled as cellulosic for the fashion fabric and regenerated for acetate. Depending on the end-uses, other structural and performance attributes could be chosen.

\section{References}

1. Chowdhary U (2009) Textile analysis, quality control and innovative uses. Deer Park, Linus, New York, USA.

2. Elasher E, Dubrovski P (2008) The influence of the weave and the method of stitching on selected mechanical properties of woven double fabrics. AUTEX Research Journal 8(2): 41-43.

3. Uttam D, Sethi R (2016) Impact of repeated washings on dimensional stability and fabric physical factors of woven cotton fabric. International Journal of Research in Engineering and Applied Sciences 6 (2): 126-135

4. Chowdhary U (2017) Comparing three brands of cotton t-shirts. AATCC Journal of Research 4(3): 22-33.

5. Chwodhary U, Wroblewski SM (2016) Textile analysis: Laboratory manual. Ronkonkoma, Linus, New York, USA.

6. Annual Book of ASTM Standards (2015) Conshohocken, ASTM, Pennsylvania, United States. Vol 1-2.

7. Technical manual of the American Association of Textile Chemists and Colorists (2016) Research Triangle Park, American Association of Textile Chemists and Colorists, North Carolina, USA, pp.67-77 (c) Creative Commons Attribution 4.0 International License

For possible submissions Click Here
Submit Article

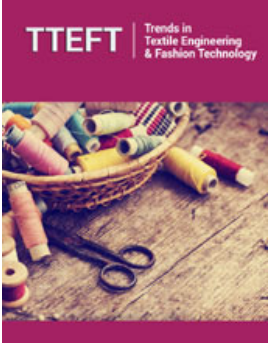

Trends in Textile Engineering \& Fashion Technology

\section{Benefits of Publishing with us}

- High-level peer review and editorial services

- Freely accessible online immediately upon publication

- Authors retain the copyright to their work

- Licensing it under a Creative Commons license

- Visibility through different online platforms 